\section{Progress of the Post Office}

$\mathrm{I}^{\mathrm{N}}$ an address delivered to the meeting of the Portsmouth Brotherhood at Portsmouth on October 18, Mr. J. H. Brebner, the controller of press information for the General Post Office, gave a brief account of the history of the Post Office. $\mathrm{He}$ laid stress on the fact that in the early days, about 1800 , the Post Office was considered more as an instrument for taxation than as an undertaking to be run for the benefit of the public.

In 1801 the Post Office was called on to make a contribution of $£ 150,000$ to the Exchequer. The Secretary of that date thought that this was an excellent opportunity to remedy what he considered a grave defect in its system of charging, namely, that the postage was the same whatever distance the letter was delivered, while obviously the charge should vary with the distance. He therefore fixed new rates proportional to the distance the letter travelled. In 1812, for example, the postage from London to Portsmouth was $8 d$. and from London to Thurso 5s. A consequence of these high rates was that the illegal conveyance of letters became general. To stop this, prosecutions were undertaken whenever evidence became available. Sometimes hundreds of prosecutions were proceeding simultaneously, and in one case in Scotland there were twelve hundred.

It is instructive to learn that owing to the increased long-distance telephone traffic, an extensive programme of underground cables costing $£ 4,500,000$ will be carried out this year. The traffic has increased so rapidly that to enable additional circuits to be provided in advance of the completion of the new cables, schemes are in hand for doubling the capacity of many of the existing four-wire trunk circuits by dividing them into two-wire circuits. Telephone lines more than 100 miles in length will be provided by means of a twelve-channel carrier system, from which twelve telephone circuits will be obtained. This compares with one circuit by normal methods. In this new system, at repeater stations, at every twenty miles, the power of the speech currents can be amplified 100,000 times. The first twelve-channel system will be brought into use between Bristol and Plymouth about the end of this year.

Those who think that radio communication has displaced submarine cables will be surprised to learn that arrangements have been made for the laying of two submarine cables of a new type between Great Britain and Holland, and for one new cable to Ireland. The two Anglo-Dutch cables will provide eleven circuits and the Anglo-Irish cable will provide eight circuits. It is anticipated that further circuits to meet the ever-increasing traffic will be obtained by the installation of additional terminal equipment at a later date.

In conclusion, Mr. Brebner said that the Post Office, by pursuing a policy of reducing the charges for its various services, has grown to be the largest employer of labour in the country. Its ever-increasing profits approximate thirteen millions annually; telephone calls last year were 1,800 million, showing an increase of 140 million over the preceding year. The remarkable progress of recent years is due to the recognition of the fact that the Post Office should work for the common weal. The results which have been achieved fully justify this policy.

\section{Educational Topics and Events}

Cambridge.-D. H. Valentine, of St. John's College, has been appointed curator of the Botanical Museum and Herbarium.

The degree of M.A. has been conferred on Dr. D. J. Bell, University lecturer in biochemistry.

At Trinity College, the following have been elected into fellowships : Dr. N. Feather, on appointment as assistant lecturer in natural sciences, M. H. L. Pryce, for research in mathematics, A. L. Hodgkin, for research in physiology, and T. T. Paterson, for research in geology.

Glasgow.-Dr. J. W. McNee, University College, London, has been appointed regius professor of the practice of medicine.

The Rector, Sir Ian Colquhoun, is delivering his rectorial address in St. Andrew's Hall, Glasgow, on October 23, at 11 a.m., and a luncheon in his honour is being held in the Bute Hall of the University.

Prof. J. Graham Kerr, M.P., has presented to the Zoological Department of the University a very valuable collection comprising all his zoological manuseripts and the material on which the work was based, including a unique series of Lepidosiren and Spirula, Budgett's collections of Protopterus, and Minchin's slides and material illustrating his study of sponges. Many other collections of great historical interest are included, and will form a basis for many future investigations. In addition, the gift comprises a collection of more than seven thousand books and pamphlets together with various scientific apparatus, and a unique series of demonstration slides which had been accumulated during his long tenure of the chair at Glasgow. In accordance with Prof. Graham Kerr's wishes, the further study of the research material included in this gift is to be restricted to fully qualified investigators, and their work must be carried out in the Department of Zoology at the University.

Prof. F. O. Bower has presented a valuable Zeiss microscope, together with a very complete series of objectives, for the use of research students in the Department of Botany.

Mr. Lewis H. Littlejohn, of the Botany Depart ment, has been awarded a Colonial agricultural research scholarship, and is spending one year at Cambridge and the second year in Trinidad.

NURSERY education problems were dealt with in two papers read before Section L of the British Association on September 11 : one by Miss I. Jones on "Nursery Education in Lancashire" and one by Mrs. M. Wintringham on "Emergency Open-air Nurseries in the Distressed Areas". Both papers comment on the favourable influence nursery schools are capable of exerting not only on the children in them but also on the homes from which they come. Miss Jones described two successfully working examples of nursery education : one in "The Tannery School" comprising a full range of classes with children of ages 3-14 years, where older girls are serviceable in the nursery class, finding thus an outlet for mothering instincts, older boys cultivate and keep in order a school garden, and part of the playing field is available for use by toddlers ; the other in "The Titan Works School", having only children up to the age of eleven; here conditions point to development into a 'home school' in which parents intimately co-operate 
with teachers in meeting the needs of the few nursery children. Mrs. Wintringham said of children who have been cared for in the open-air nurseries in distressed areas that "in all cases the teachers of the infant schools, where the children go afterwards, notice how much more alert they are, more independent and adventurous-willing to try" than the other infants. On the question of the effect on family life of "taking the children away from their mothers", she says there are many instances of little reforms and improvements in the personal habits and domestic life of the parents due to the nursery school training.

Mr. E. I. Lewis has issued a pamphlet, "Preparation for Businesș Careers" (W. Heffer and Sons, Cambridge. 1s. net), advocating a course of teaching during the last year of school life which should be a bridge between school and business. Mr. Lewis's ideas were originally presented in an address to a conference of public school masters. He appears to have in mind mainly boys receiving education of a public school or similar type. He does not attempt to deal, "for our present purposes with students in technical schools, colleges or universities. . . ." Mr. Lewis's suggested course aims at avoiding sectional-mindedness and at producing a view of business as a whole, its several parts working to one end. He realizes the present hampering quality of examinations, and sees that only by a new educational treatment can over-specialization be avoided. He makes points which are not new but are in constant need of emphasis. Classical masters, for example, extol the artistic conception of ancient peoples, but neglect their workmanship and their organizing genius. "Whoever would appraise Egyptian, Greek or Roman engineers might with profit consult their living successors". The treatment of subjects, chemistry for example, in vast detail at too early a stage imposes uneven development and imperils chances of promotion to administrative posts where scientific training is needed. No chemist should be content with an education based solely upon the branches of knowledge which directly meet his professional needs; he should enjoy a liberal education, from which flows broad interests, corrective of the narrowness that threatens men who follow professions shut off from the everyday affairs of their kind. With all of which no one who desires to see the scientific worker accorded his proper sphere in the administration of a scientific and industrial world will disagree. Mr. Lewis gives an outline of the subjects of the proposed "Bridge Course", which is the more stimulating since they will by no means find universal agreement.

\section{Science News a Century Ago}

\section{Population of England and Wales}

The Times of October 26, 1836, contained an article by T. R. Edmonds, author of "Life Tables", on the "Density of the English Population". "The rapid increase of the English population", he said, "during the last 30 or 40 years is one of the most decisive manifestations of our national prosperity. Whilst other European nations are increasing their food and population at the rate of 8 per cent. every ten years, the population of England is increasing at the rate of 16 per cent every 10 years. The density of the English population is now much greater than that of any other European nation, with the ex. ception of the Netherlands, which being the commercial depot of Germany, is not a fair comparison. In the different counties of England the variations in the density of the population are very considerable; in the manufacturing counties the density is nearly twice as great as in the agricultural counties. ... In the year 1821, the mean density of the population of England and Wales was represented by 207 inhabitants to each square mile; in 1831 there were 240 to each square mile; and in 1841 there will be 278 inhabitants to each square mile. . . The com. parative densities of the population in the different counties of England is a subject of some importance to the nation and to capitalists. A given extent of territory may, with few exceptions, be presumed to be wealthy or productive in proportion to the density of the population." The article was accompanied by a table of the counties showing the area and the number of inhabitants per square mile; the latter ranging from 4,817 in Middlesex to 72 in Westmoreland.

\section{Death of William Lax, F.R.S.}

ON October 29, 1836, the death took place of the Rev. William Lax, the third Lowndean professor of astronomy at Cambridge. Born in 1761, Lax graduated in 1785 from Trinity College, Cambridge, as senior wrangler ; he was a Smith's prizeman, and was afterwards elected a fellow of his college. In 1795, at the age of thirty-four years, he was chosen to succeed Dr. John Smith in the Lowndean chair of astronomy and geometry, and after several years spent in tuition was presented to the livings of Marsworth, Bucking. hamshire, and St. Ippolyts in Hertfordshire. At the latter place he erected a small observatory, and it was there he died at the age of seventy-five years. Lax was elected a fellow of the Royal Society in 1796, and in 1799 and 1808 respectively he contributed memoirs to the Society on "A Method of Finding the Latitude of a place by means of the Altitude of the Sun", and "On a Method of examining the Divisions of Astronomical Instruments". His "Tables to be used with the Nautical Almanac" was published by the Board of Longitude in 1821. In Lax's time, the University of Cambridge possessed no observatory, and it was due to his successor, George Peacock (1791-1858), Dean of Ely, that one was erected.

\section{The Brussels and Antwerp Railway}

The first railways to be planned in Belgium were those between Ostend and Liège and Antwerp and Valenciennes, and portions of these were opened in 1836. Referring to the railway line between Antwerp and Brussels, the Athenceum of October 29, 1836, said : "We learn from Le Voleur that this undertaking, which has been in operation only a few months, has already met with great success. The following is an account of the number of passengers who availed themselves of it in the first four months. In May 101,000; in June 98,000; in July 112,000; in August 117,000; total 428,000. . . This result is extraordinary. The number exceeds that of the travellers by the Manchester and Liverpool Railway, which is upon the average only 80 per train whilst upon the above it is 200 . The average price is $1 \mathrm{fr}$. per person, and the receipts for the four months in question are more than 430,000 frs., which gives an interest of 5 per cent. on the capital." 